\section{Orthostatic Intolerance after Artificial Heat Acclimatization in Physically Fit Subjects}

THE incidence of heat syncope (temporary stoppage of respiration and circulation) is greater in persons unacclimatized to heat ${ }^{1}$, and heat acclimatization improves orthostatic tolerance in hydrated men ${ }^{2}$, but the latter has not been confirmed. We thought that artificial heat acclima. tization (acclimimation) might increase orthostatic tolorance in men exposed to the combined stresses of heat, exercise and dehydration, and have worked from this idea.

Four physically fit young men (mean age 24) were given a standard $70^{\circ}$, head-up, 10 min tilt-test following a $2 \mathrm{~h}$ walk at $6.4 \mathrm{~km} / \mathrm{h}$ at $47^{\circ} \mathrm{C}$ dry bulb temperature (DBT) and 33 per cent relative humidity $(\mathrm{RH})$ after the first exposure (control test walk, CTW) and after the eighth similar exposure (acclimatization test walk, ATW). The tilt-table tests were conducted at $24^{\circ} \mathrm{C} \mathrm{DBT}$ and 50 per cent RH $10 \mathrm{~min}$ after the heat exposures with the subjects supported by a saddle with no foot-rest. Water was freely available during the heat exposures. A detailed description of the experimental procedures has been published before ${ }^{3}$.

During the eight acclimatization exposures, average $( \pm S . D$.$) sweat rates increased from 624+49 \mathrm{~g} / \mathrm{m}^{2} \times \mathrm{h}$ on the first exposure to $934 \pm 38 \mathrm{~g} / \mathrm{m}^{2} \times \mathrm{h}$ by the eighth exposure and average pulse rates decreased from $174 \pm$ 4 beats/min to $166 \pm 11$ beats/min (results from the second hour of exercise).

All four subjects completed the control tilt easily, but unexpectedly three of them had to be lowered during the first $5 \mathrm{~min}$ of the acclimatization tilt because of nausea, profuse sweating and syncope. At the moment of syncope the average ratio of systolic to diastolic blood pressure was $86 / 79 \mathrm{~mm} \mathrm{Hg}$ and the pulse rate was 137 beats/min. The non-fainter, who forced his water intake to surpass slightly his total weight deficit, completed the acclimatization tilt with the least distress. His losses of plasma volume and total blood volume, however, were greater than those of the three fainters (Table 1). Also, in the fainters, the average losses of fluid volume were slightly greater during the control tilt compared with the losses during the acclimatization tilt. The total average decrease in Evans blue space (plasma volume) and total blood volume after the control test walk was 11.0 per cent and 8.2 per cent respectively, and after the acclimatization test walk was $11 \cdot 2$ per cent and 6.0 per cent respectively. In the fainters, average losses of body weight after acclimatization were rather greater than after the control test. In the non-fainter, changes in body weight were minimal. Thus analysis of fluid losses and levels of total body dehy.

Table 1. INDIVIDUAL AND AVERAGE VALUES OF TIHT-TABIJE RESPONSES AND FLIID COMPARTMENT CHANGES AFTER THF CONTROL AND ACCLIMATIZATION

\begin{tabular}{|c|c|c|c|c|c|c|}
\hline Subject & $\begin{array}{c}\text { Tilt time } \\
\text { (min) }\end{array}$ & $\begin{array}{c}\text { SBP/DBP } \\
(\mathrm{mm} \mathrm{Hg})\end{array}$ & $\begin{array}{l}\text { Heart } \\
\text { rate } \\
\text { (beats/ } \\
\text { min) }\end{array}$ & $\underset{\%}{\Delta \mathrm{PV},}$ & $\underset{\%}{\Delta \mathrm{TBV}}$ & $\begin{array}{c}\triangle \text { l Body } \\
\text { weight, } \\
\%\end{array}$ \\
\hline $\begin{array}{c}\text { Fainters } \\
\text { F. K. } \\
\text { R. W. } \\
\text { E. G. }\end{array}$ & $\begin{array}{l}\text { (CTW) } 10 \\
\text { (ATW) } 3 \\
\text { (CTW) } 10 \\
\text { (ATWW) } 4 \\
\text { (CTW) } 10 \\
\text { (A'TW) } 6\end{array}$ & $\begin{array}{c}104 / 80 \\
80 / 70 \\
106 / 102 \\
104 / 98 \\
100 / 88 \\
74 / 68\end{array}$ & $\begin{array}{l}140 \\
126 \\
144 \\
146 \\
112 \\
140\end{array}$ & $\begin{array}{r}-19 \cdot 2 \\
-9 \cdot 1 \\
-16 \cdot 4 \\
-11 \cdot 5 \\
-3 \cdot 3 \\
-10 \cdot 1\end{array}$ & $\begin{array}{r}-16 \cdot 1 \\
-3 \cdot 6 \\
-13 \cdot 8 \\
-6 \cdot 3 \\
+1.3 \\
-5.1\end{array}$ & $\begin{array}{l}-0.7 \\
-1.7 \\
-1.2 \\
-1.4 \\
-1.7 \\
-2.7\end{array}$ \\
\hline$\frac{\bar{x}}{\bar{x}}$ & $\begin{array}{l}\text { (CTW) } 10 \\
\text { (A'TW) }\end{array}$ & $\begin{array}{r}103 / 90 \\
86 / 79\end{array}$ & $\begin{array}{l}132 \\
137\end{array}$ & $\begin{array}{l}-13 \cdot 0 \\
-10 \cdot 2\end{array}$ & $\begin{array}{l}-9 \cdot 5 \\
-5 \cdot 0\end{array}$ & $\begin{array}{l}-1.2 \\
-1.9\end{array}$ \\
\hline $\begin{array}{l}\text { Non-fainter } \\
\text { J. C. }\end{array}$ & $\begin{array}{ll}(\mathrm{CTW}) & 10 \\
\left(\mathrm{~A}^{\prime} \mathrm{TW}\right) & 10\end{array}$ & $\begin{array}{l}124 / 100 \\
110 / 102\end{array}$ & $\begin{array}{l}118 \\
116\end{array}$ & $\begin{array}{r}-5 \cdot 3 \\
-13 \cdot 9\end{array}$ & $\begin{array}{l}-4 \cdot 4 \\
-8 \cdot 9\end{array}$ & $\begin{array}{l}-0.3 \\
+0.8\end{array}$ \\
\hline Total $\overline{\mathrm{X}}$ & $\begin{array}{ll}\text { (CTW) } & 10 \\
\text { (ATW) } & 6\end{array}$ & $\begin{array}{r}108 / 92 \\
92 / 84\end{array}$ & $\begin{array}{l}128 \\
132\end{array}$ & $\begin{array}{l}-11 \cdot 0 \\
-11 \cdot 2\end{array}$ & $\begin{array}{l}-8.2 \\
-6.0\end{array}$ & $\begin{array}{l}-1 \cdot 0 \\
-1 \cdot 2\end{array}$ \\
\hline
\end{tabular}

Baseline PV, TBV, and body weight were measured the evening before the test walks. The tilt measures were taken at the point of syncope or at the end of the $10 \mathrm{~min}$ tilt.

SBP, systolic blood pressure; DBP, diastolic blood pressure; PV, plasma volume; TBV, total blood volume. dration does not reasonably explain the marked orthostatic intolerance.

The two primary interrelated mechanisms influencing cardiac output when hydrostatic forces are increased are maintenance of $(a)$ the blood volume, and $(b)$ its relative distribution in the arterial and venous systems. Changes in blood volumes cannot explain the marked syncope, and so changes in blood distribution must be involved. The principal circulatory changes resulting from heat acclimatization seem to be met by repartitioning cardiac output rather than by increasing it ${ }^{4}$, which suggests that there are changes in arterial tone. Increased venomotor tone has been observed during early phases of acclimatization but not persisting as exposures continued ${ }^{5}$. Because of the larger volume of blood in the veins, a small constrictive effect would cause a much larger shift of blood than the same constriction in the arteries. Arterial dilatation of the extremities (which is an accepted means of increasing heat dissipation) probably tended to raise the capillary pressure in our expcriments, especially in the dependent parts, thereby tending to increase both distension of the blood vessels and extravasation of fluid during the tilt. Increased venomotor tone apparently decreases as acclimatization proceeds, and so we wonder whether the arterial constrictive mechanism was "deconditioned" from the demands for heat dissipation, thereby reducing its constrictive function necessary for maintenance of the cardiac output during tilting.

\section{J. E. Greenleaf}

J. S. Bosco

Biotechnology Division,

Ames Research Center, NASA,

Moffett Field, California 94035

Received March 3, 1969.

'Leithead, C. S., and Lind, A. R., Heat Stress and Heat Disorders, 136 (Davis, Philadelphia, 1964).

2 Eichna, L. W., and Bean, W. B., J. Clin. Invest., 23, 942 (1944).

Greenleaf, J. E., Douglas, L. G., Bosco, J. S., Matter, jun., M., and Blackaby, J. R., Intern. J. Biometeorol., 11, 311 (1967) Rowell, L. B., Kraning, K. K., II, Kennedy, J. W., and Evans, T. O.,

${ }^{5}$ Wood, J. E., and Bass, D. E., J. Clin, Invest., 39, 825 (1960).

\section{Reaction of Detergents with Amoeba proteus}

Amoeba proteus moves by the formation of pseudopodia in the direction of travel, and the formation of new pseudopodia may be induced by small local concentrations of some proteins and cationic detergents which are believed to react with anionic groups on the cell surface and lower the surface charge ${ }^{1,2}$. The importance of changes in net surface charge in providing a mechanism for cell surface transformations has also been emphasized by other workers ${ }^{3}$. Staining reactions with alcian blue and with toluidine blue show that the surface coat of amoebae is probably composed of negatively charged polysaccharides or mucopolysaccharides ${ }^{4}$. The haemolytic properties of detergents are well known and, for a series of 12-carbon detergents, are consistent with a reaction involving penetration of a lipid film ${ }^{5}$. If the mechanism which we have proposed to account for pseudopodium induction by these compounds is correct ${ }^{2}$, then the lysis of $A$. proteus by detergents should depend on their reactivity with negatively charged groups on the surface polysaccharide rather than on their ability to penetrate a lipid film.

Washed, starved cells of $A$. proteus (strain X65), grown in mass culture with Tetrahymena pyriformis in Chalkley's solution ${ }^{2}$, were immersed in solutions of $\mathrm{Na}$ laurate, Na dodecyl sulphate, dodecylamine $\mathrm{HCl}$, dodecyl. dimethylamine $\mathrm{HCl}$ and dodecyltrimethylamine bromide at concentrations ranging from $5 \times 10^{-3} \mathrm{M}$ to $2 \times 10^{-5} \mathrm{M}$ in 